\title{
A Case Report : TMJ Osteoarthritis in a Patient with Renal Osteodystrophy
}

\author{
Gi-Ho Lee, D.D.S.,M.S.D. \\ Department of Oral Medicine, School of Dentistry, Dankook University
}

\begin{abstract}
Renal osteodystrophy $(\mathrm{RO})$ is characterized by skeletal changes in patients with renal disease and developed as a result of alterations in the metabolism of calcium, phosphate and secondary hyperparathyroidism. Bony changes in the craniofacial region include decreased bone density, radiolucent lesions(brown tumors), depletion of cortical bone and loss of lamina dura, but such changes rarely occur in the temporomandibular joint(TMJ). We report an uncommon case of bony changes and pain of both TMJs in a patient with RO. A 41-year-old man with RO came to our clinic due to TMJ pain and sounds. Occlusal change was also reported. Radiographs revealed degenerative changes of the both condyles. The patient had medical history of renal cancer therapy and hemodialysis. The patient was diagnosed with TMJ arthritis of $\mathrm{RO}$ and referred for systemic management through medication of calcium and vitamin $\mathrm{D}$ and parathyroidectomy. At 15-month follow-up, most of TMD symptoms disappeared and second radiographs revealed that bone density and cortical thickness of the mandible increased and the skeletal outline of the both condyles became relatively clear. As bony changes may begin in the early stage of the renal disease, dentists should be alert to detect the sign of the disease. In addition, it is important to differentiate TMJ arthritis of systemic cause because the treatment protocol is quite different.
\end{abstract}

Key words: Osteoarthritis, Renal osteodystrophy, Temporomandibular joint

\section{I . INTRODUCTION}

Renal osteodystrophy $(\mathrm{RO})$ is characterized by skeletal complications in patients with end-stage renal disease ${ }^{1)}$. With the rapid expansion of dialysis and transplantation programs in the 1960s and 1970s, $\mathrm{RO}$ has emerged as one of the major causes of

\footnotetext{
Cheonan 330-714, Republic of Korea.

Phone: +82-41-550-0203

Fax: $+82-41-5500-116$

E-mail: leegida@hanmail.net

Received: 2013-06-22

Revised: 2013-08-07

Accepted: $2013-08-26$
}

Corresponding author: Gi-Ho Lee

Department of Oral Medicine, College of Dentistry,

Dankook University, 119 Dandaero, Dongnam-gu, morbidity among patients receiving renal replacement therapy ${ }^{2,3)}$.

$\mathrm{RO}$ is most often derived from secondary hyperparathyroidism associated with all four parathyroid glands, as a meaning of alterations in the metabolism of calcium and phosphate ${ }^{4)}$. When the glomerular filtration rate decreases below 25\% of normal, phosphate excretion is impaired. This results in an elevated tissue phosphate concentration. hyperphosphatemia leads to hypocalcemia because an elevated tissue phosphate concentration decreases renal synthesis of calcitriol (1,25dihydroxyvitamin D3), the active form of vitamin D3. Absorption of calcium in the gut depends on calcitriol ${ }^{5)}$.

The resorptive effect of parathyroid hormone on bone usually starts early in the course of chronic 
kidney disease. The characteristic histologic features of $\mathrm{RO}$ are variable and classified according to the state of bone turnover: High turnover bone disease or osteitis fibrosa cystica represents the manifestation of hyperparathyroidism, characterized by increased osteoblastic /clastic activity and peri-trabecular fibrosis. Low turnover bone disease includes: osteomalacia, or defective mineralization (nonspecific mineralization) of osteoid, osteopenia or osteoporosis $^{6)}$ (Fig. 1)

Common radiographic findings of $\mathrm{RO}$ consist of subperiosteal erosions in the terminal phalanges, long bones, and jaws. Bony changes in the craniofacial region include decreased bone density, radiolucent lesions (brown tumors) ${ }^{7,8,9)}$ depletion of cortical bone and loss of lamina dura but such changes rarely occurred in the temporomandibular joint $(\mathrm{TMJ})^{10,11}$. So, I report an uncommon case of bony changes and pain of both TMJs in a patient with $\mathrm{RO}$.

\section{CASE REPORT}

A 41-year-old man came to Department of Oral Medicine, Dankook University Dental Hospital due to pain and grating sounds of left. TMJ on Feb. 2011. The patient had been receiving hemodialysis for 10 years and had bilateral nephrectomy due to renal cancer three months ago. His chief complaints began after nephrectomy and jaw pain occurred when chewing with intensity of 6-7 in VAS (visual analogue scale, $0-10$ ), and there was no spontaneous pain. His opening was within normal limits; Comfortable mouth opening (CMO) was $38 \mathrm{~mm}$ and active range of motion (AROM) was $50 \mathrm{~mm}$ with overjet of $0 \mathrm{~mm}$ and overbite of $-0.9 \mathrm{~mm}$ (anterior

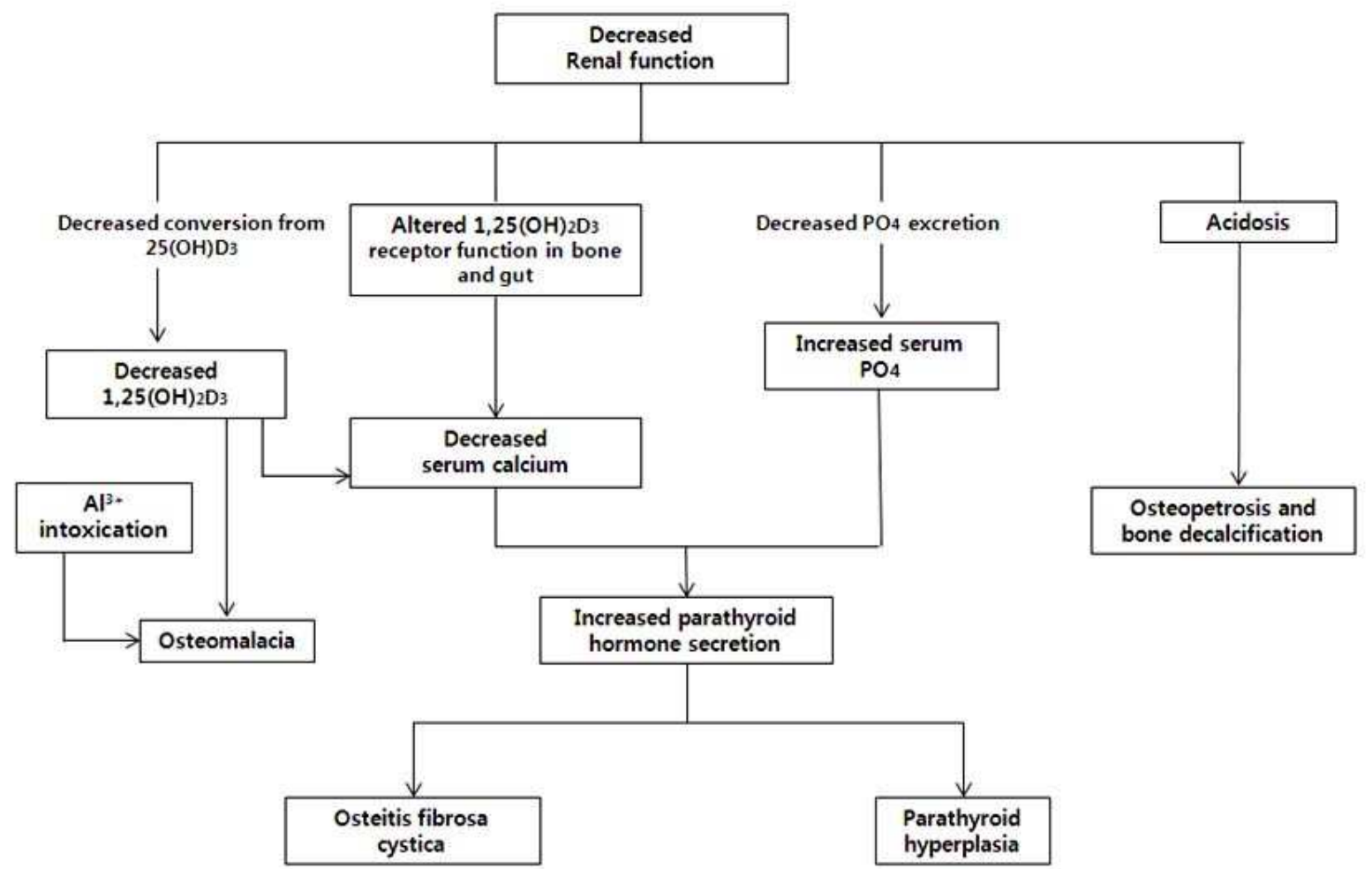

Fig. 1. Flowchart for the development of bone, phosphate, and calcium abnormalities in chronic renal failure (CRF). 


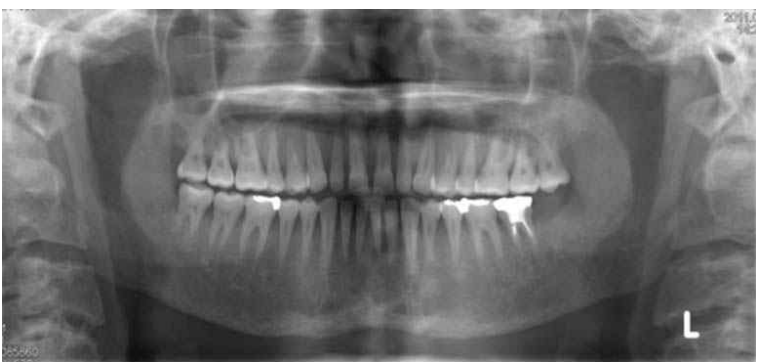

Fig. 2. Panoramic view taken at the first visit, 3 months after renal cancer surgery, indicates reduced bony density (relatively prominent the teeth), loss of lamina dura and cortical border of the mandibular canal, poorly outlined mandibular cortex and erosion of the condylar head.

openbite). There was no deviation or deflection in his opening. There was pain on left TMJ by lateral excursion to the left side and protrusive movement of the jaw. Tenderness at the posterior to left TMJ was reported during digital palpation. Resistance test also provoked pain.
The panoramic radiograph revealed degenerative changes of the both condyles, overall loss of lamina dura and decreased jaw bone density (Fig. 2). However, as there were no marked changes on the transcranial view except blurred TMJ (Fig. 3), cone-beam computed tomography (CBCT) was recommended. As shown in Fig. 4, CBCT revealed severe destructive changes in both the condylar heads of the mandible, reduced bony density and poorly outlined mandibular cortex.

He was diagnosed as ;

1. Degenerative joint disorder on both TM joints (possibly derived from renal osteodystrophy).

2. Masticatory muscle pain on Lt. pterygoid muscle. 3. Retrodiscitis on Lt. TMJ

To lessen his pain and symptoms, behavioral modification including stress control, relaxation, occlusal disengagement, relaxation and dietary instruction was encouraged and analgesics and muscle relaxants were given (acetaminophen 650mg, eperisone 50mg twice a day). At three-week follow-up, pain decreased a bit but still presented

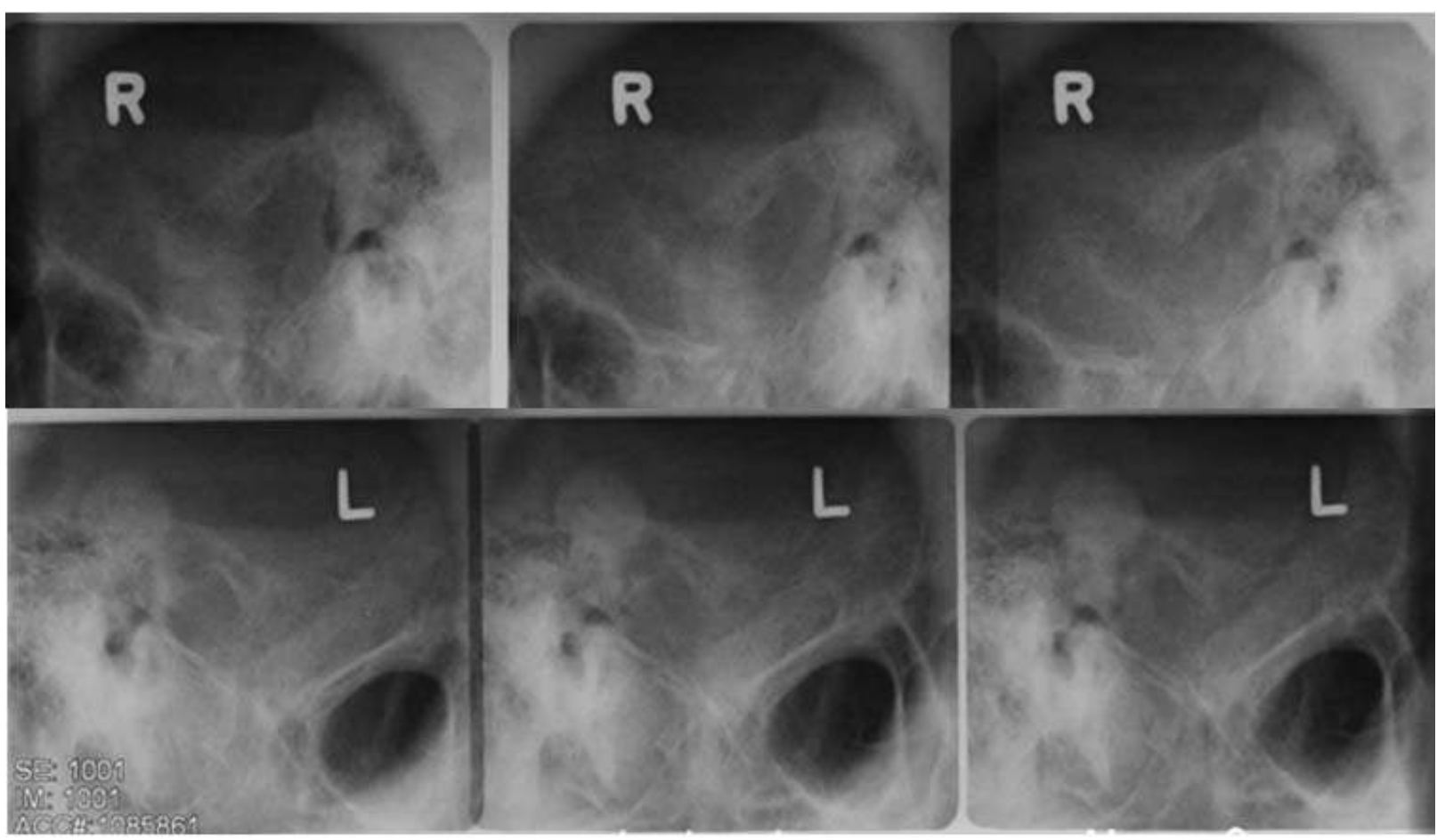

Fig. 3. Transcranial view at the first visit illustrates reduced bony density and poorly outlined mandibular cortex. 
with chewy food with intensity of VAS 6 .

Based on the CBCT features and medical history of renal disease, the patient was finally diagnosed as osteoarthritis of both TMJ manifested in the course of RO. Generally, skeletal alterations in RO regress after parathyroidectomy ${ }^{12)}$. As he was supposed to take medication of calcium and vitamin $\mathrm{D}$ and parathyroidectomy to manage $\mathrm{RO}$ at that time, we decided not to provide any active intervention for TMD but to prescribe analgesics. At 15-month follow-up after subtotal parathyroidectomy, most of TMD symptoms such as pain and crepitus disappeared and newly-taken radiographs revealed that bony density and cortical thickness of the mandible increased and the skeletal outline of the both condyles became relatively clear (Fig. 5, 6). But

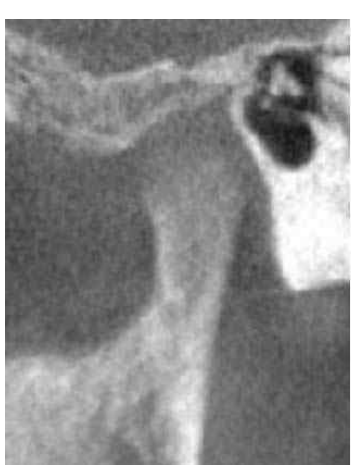

(A)

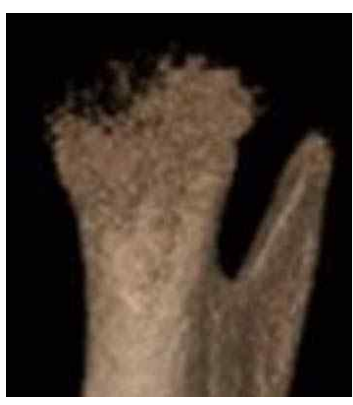

(C)

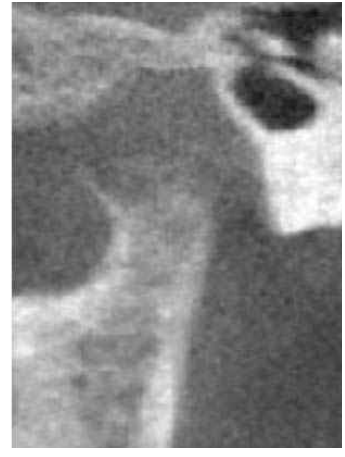

(B)

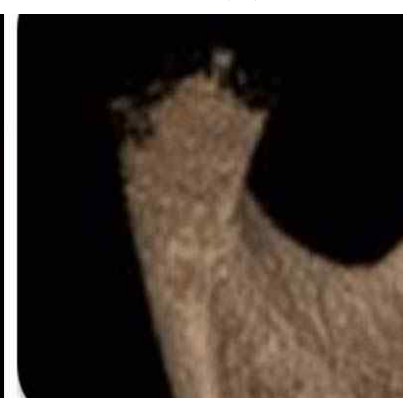

(D)
Fig. 4. CBCT (cone beam $\mathrm{CT}$ ) revealed severe destructive changes in both the condylar heads of the mandible, reduced bony density and poorly outlined mandibular cortex. (A) Sagittal view of right and (B) left TMJs. (C) 3-dimensional reconstructed image of right and (D) left TMJs. open bite still persisted.

The patient has been receiving calcium and vitamin D and having regular follow-ups with his physician.

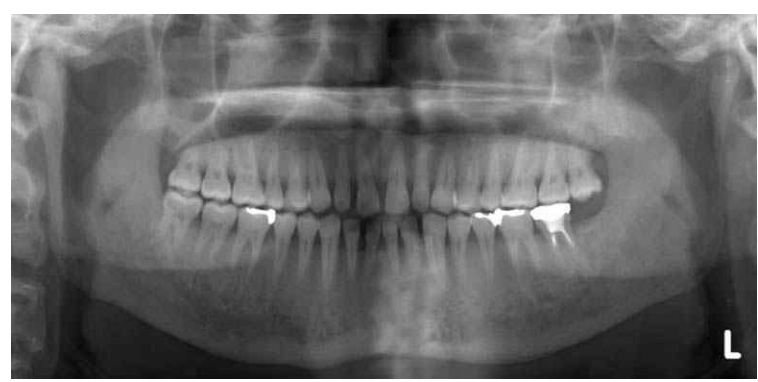

Fig. 5. Panoramic view taken after 15 months later reveals increased bony density and cortical thickness of the mandible.

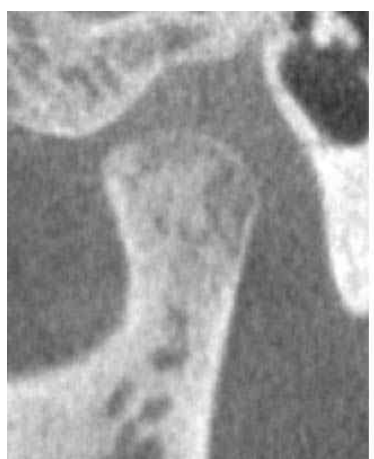

(A)

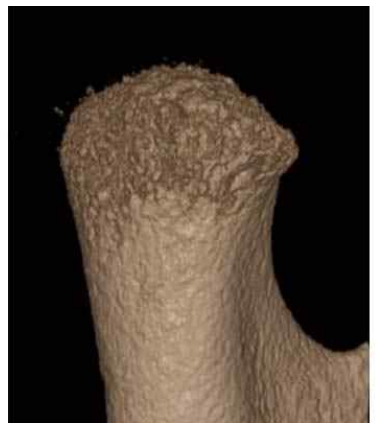

(C)

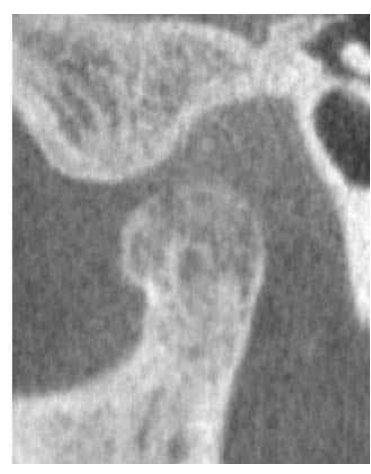

(B)

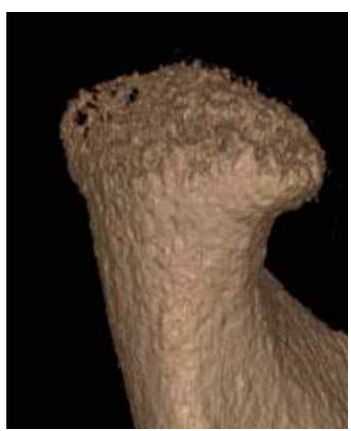

(D)
Fig. 6. CBCT taken 15 month after the first visit illustrates increased bony density and cortical thickness of mandible, relatively clear skeletal outline of the both condyles. (A) Sagittal view of right and (B) left TMJs. (C) 3-dimensional reconstructed image of right and (D) left TMJs. 


\section{DISCUSSION}

$\mathrm{RO}$ is the metabolic bone disorder accompanying chronic impairment of renal glomerular function, and comprises a collection of disorders of mineral and skeletal metabolism which may occur singly or in combination. It is multifactorial disease and because of this there is a wide heterogeneity in its expression and clinical impacts.

In general, $\mathrm{RO}$ is usually diagnosed after treatment for end-stage renal disease begins. Blood tests will indicate decreased calcium and calcitriol (vitamin D) and increased phosphate and parathyroid hormone. $\mathrm{X}$-rays will also show bone features of renal osteodystrophy (chondrocalcinosis at the knees and pubic symphysis, osteopenia and bone fractures) but may be difficult to differentiate from other conditions.

In radiological features which may occur in patients undergoing long term hemodialysis for chronic renal failure have been described by others, and include osseous hypomineralization, subperiosteal and periarticular bone resorption, and soft tissue calcification in all the body ${ }^{11)}$. It is not strange that skeletal deformity which comes from arthritis can be seen in TMJ.

There are some diseases that can present with TMJ arthritis: rheumatoid arthritis ${ }^{12)}$, psoriatic $\operatorname{arthritis}^{13)}$, systemic lupus erythematosus ${ }^{14)}$, familial Mediterranean fever ${ }^{15)}$, gout ${ }^{16)}$ and Sjögren's syndrome ${ }^{17-18)}$. As these diseases commonly present with polyarthritis, pain on jaw function, crepitus, and muscle tenderness and their radiographic features are not specific, serologic and histologic examination and thorough medical history is mandatory for their differentiation. Pathognomonic signs of each of these diseases are presented in Table 1.

Though few cases have been reported that RO has affected the TMJ $^{19,20)}$, Dick and Jones ${ }^{21)}$ reported that the incidence of bony changes in the TMJ related with $\mathrm{RO}$ is greater than has been suspected previously. As most such patients have no symptoms and TMJs are not examined as a routine for patients with RO, TMJ arthritis with RO seems to be rarely detected. As bony changes usually begin in the early stage of the renal disease, dentists should be alert to detect the sign of the disease to provide the appropriate cause-related therapy.

So, it is important to differentiate TMJ arthritides of other systemic causes because their therapeutic approaches are quite different.

Hartmut et $\mathrm{al}^{22)}$ stated that three major therapeutic groups are available for the management of $\mathrm{RO}$ : phosphate binders, vitamin $\mathrm{D}$ or vitamin $\mathrm{D}$ analogues, calcimimetics, and parathyroidectomy would be recommended to treat $\mathrm{RO}$. On the basis of these modalities, dietary changes, many kinds of supportive therapies would be required for pain relieving or inhibiting from worsening in case of joint pain.

In this case, the patient was diagnosed as TMJ osteoarthritis with $\mathrm{RO}$ and referred for systemic management through medication of calcium and

Table 1. Systemic diseases presenting with TMJ arthritis

\begin{tabular}{ll}
\hline & Pathognomonic signs \\
\hline \hline Rheumatoid arthritis & Positive rheumatoid factor or ACPA, abnormal CRP or ESR \\
Psoriatic arthritis & Psoriasis, negative rheumatoid factor \\
Systemic lupus erythematosus & Butterfly rash \\
Familial Mediterranean fever & Brief, self-limiting attacks of fever \\
Gout & Hyperuricemia, tophaceous arthritis, MSU crystal deposits in the tophus \\
Sjögren's syndrome & Dry eyes and dry mouth, \\
\hline
\end{tabular}


vitamin D and parathyroidectomy. At 15-month follow ${ }^{-}$up, most of TMD symptoms disappeared and second radiographs revealed that bone density and cortical thickness of the mandible increased and the skeletal outline of the both condyles became relatively clearer.

Though TMD symptoms in patients with $\mathrm{RO}$ may be improved through systemic management, the dentist may help the patient to reduce the pain by physical therapy, occlusal splint and behavioral modification training such as relaxation, occlusal disengagement, dietary instruction, application of hot pack. But, to have additional benefit in relieving pain safely, it could be better to consult with physician to prescribe medicine.

\section{REFERENCES}

1. Syrjanen S, Lampainen E. Mandibular changes in panoramic radiographs of patients with end stage renal disease. Dentomaxillofac Radiol 1983;12:51-56.

2. Kanis J.A., Cundy T.F., Hamdy N.A.T. Renal osteodystrophy. Bailliere's Clinical Endocrinology and Metabolism 1988;2:193-241.

3. John E.Z., Caner, John L. Decker. Recurrent acute (? Gouty) arthritis in chronic renal failure treated with periodic hemodialysis. Am J Med 1964;36:571-582.

4. Fishman MC. Medicine. $4^{\text {th }}$ ed. Philadelphia, 1996, Lippincott. Raven Publishers; pp 187-196.

5. Koch Nogueira PC, David L, Cochat P. Evolution ofsecondary hyperparathyroidism after renal transplantation. Pediatr Nephrol 2000;14:342-346.

6. Drueke TB. The pathogenesis of parathyroid gland hyperplasia in chronic renal failure. Kidney Int 1995;48:259-272

7. Spolnik KJ, Maxwell DR, Patterson SS, Kleit SA, Cockerill EM, Dental radiographic manifestations of end-stage renal disease. Dent Radiogr 1981;54:21-31.

8. Eastwood JB. Renal osteodystrophy: a radiological review. CRC Crit Rev Diagn Imaging 1977;9:77-104.

9. Silverman S, Gordan G, Grant T, et al. The dental structures in primary hyperparathyroidism: studies in 42 consecutive dentulous patients. Oral Surg Oral Med Oral Pathol 1962;15:426-436.

10. John R, Timothy L. : Oral manifestations of renal osteodystrophy : case report and review of the literature. Spec Care Dentist 2003;23:28-34.
11. Johnson, C., Benjamin Graham, C., Kingsbury Curtis, F. Roentgenographic manifestations of chronic renal disease treated by periodic haemodialysis. American Journal of Roentgenology 1967;101:915-926.

12. A.J. Sidebottom, R. Salha. Management of the temporomandibular joint in rheumatoid disorders. $\mathrm{Br}$ J oral Maxillofac Surg 2013;51:191-198.

13. L Lamazza, F Guerra, M Pezza, AM Messina, A Galluccio, M Spink, A De Biase. The use of etanercept as a non-surgical treatment for temporomandibular joint psoriatric arthritis: a case report. Australian Dental Journal 2009;54:161-165.

14. Roland Jonsson, Ann-Marie Lindvall, Gudrun Nyberg. Temporomandibular joint involvement in systemic lupus erythematosus. Arthritis and Rheumatism 1983;26:1506-1510

15. Ferit Tovi, Albert Gatot, Dan Fliss. Temporomandibular arthritis in familial mediterranean fever. HEAD \& NECK 1992;14:492-495.

16. Zsuzsanna Suba, Dániel Takács, Szabolcs Gyulai Gaál et al. Tophaceous gout of the temporomandibular joint: A report of 2 cases, J Oral Maxilofac Surg 2009;67:1526-1530.

17. Vivino FB, Katz WA. Sjögren's syndrome: clinical picture and diagnostic tests. J Musc Med 1995;12: 40-52

18. Al-Hashimi I, Khuder S, Haghighat N, Zipp M. Frequency and predictive value of the clinical manifestations in Sjögren's syndrome. J Oral Pathol Med 2001;30:1-6.

19. Lighterman, L. Renal osteodystrophy with oral manifestations. J Oral Surg 1952;10:233.

20. Alvin Sellers, Alan C. Winfield, Shaul G. Massry. Resorption of condyloid process of mandible. An unusual manifestation of renal osteodystrophy. Arch Intern Med 1973;131:727-728.

21. Dick R., Jones D. N. Temporomandibular joint changes in patients undergoingchronic haemodialysis. Clin Radiol 1973;24:72-76.

22. Hartmut H. Malluche, Hanna Mawad, Marie-Claude Monier-Faugere. Effects of treatment of renal oseodystrophy on bone histology. Clin J Am Soc Nephrol 2008;3:S157-S163. 
국문초록

\section{턱관절의 골관절염을 동반한 신성골이영양증 환자 증례보고}

이기호

단국대학교 치과대학 구강내과학교실

신성골이영양증 (Renal osteodystrophy)은 만성 신질환 환자에서 관찰되는 골격성 변화를 특징으로 하는 질환으로 칼슘과 인 대사의 변화, 그리고 이차성 부갑상선 기능항진증의 결과로 나타난다. 방사선학적으로 지골의 말단, 장골과 악골 부위의 골막하 부위의 침식을 흔하게 관찰할 수 있다.

악안면 영역에서 골변화는 골밀도의 감소, 방사선 투과성 병소 (갈색 종양 : brown tumor), 피질골의 비박화와 치조백선의 소실을 보인다. 그러나 이러한 골변화가 악관절에 발생하는 것은 흔치 않은 일이다. 본 증례는 양측 하악 과두의 골변화를 보인 신성골이영양증 환자를 보고하고자 한다.

지난 10년 간 혈액 투석 치료와 3개월 전 신장암 수술 병력이 있는 41세 남자 환자가 좌측 턱의 통증을 주소로 2011년 2월 단국대학교 치과대학부속 치과병원 구강내과에 내원하였다. 양측 악관절의 골관절염과 유사한 방사선학적 소견을 보였 고, 전치부 개방교합이 관찰되었다. $\mathrm{CBCT}$ 를 이용한 방사선학적 특징과 생화학적 지표를 통해 신성골이영양증으로 인한 양 측 턱관절의 골관절염으로 진단 되어 환자는 내과에서 신성골이영양증의 치료 방법의 하나인 칼슘 및 비타민 $\mathrm{D}$ 복용고 부갑 상선 절제술을 시행 받았고, 그 동안 턱관절의 통증 조절을 위해 본원에서는 행동 요법과 약물 치료, 물리치료만 시행하였다. 약 1 년 3 개월 후 재검사에서 하악골의 골밀도와 피질골 두께가 증가하였고, 하악 과두 외형이 비교적 명확하게 바뀌었다. 골변화는 만성 신장 질환의 초기 단계부터 시작되므로 치과의사는 이러한 질환의 징후 및 가능성을 신속히 감별할 수 있어야 한다. 또한 골관절염과 신성골이영양증의 치료 프로토콜이 다르기 때문에 두 질환을 감별하는 것이 중요하다.

주제어: 골관절염, 신성골이영양증, 턱관절 